\title{
The Irish in Mercia: A Cultural Context for the Earliest Anglo-Saxon Prayer Books
}

\author{
Kirsty March
}

School of English , UCC

1st soldier: You're using coconuts!

King Arthur: What?

1st soldier: You've got two empty halves of coconut and you're bangin' 'em together.

King Arthur: So? We have ridden since the snows of winter covered this land, through the kingdom of Mercia, through . . .

1st soldier: Where'd you get the coconuts?

King Arthur: We found them.

1st soldier: Found them? In Mercia?! The coconut's tropical!

(Monty Python and the Holy Grail, 1975, directed by Terry Gilliam and Terry Jones)

Mercia is a county in the English midlands, and its foundation dates to the sixth century. In studies of the Anglo-Saxon period, Mercia is overshadowed by its neighbour Northumbria as famous works of art such as, the Cuthbert Cross and Lindisfarne Gospel Book were manufactured in Northumbria. However, Mercia produced manuscripts which are thought to be the earliest surviving European devotional prayer books. My research focuses on these Mercian manuscripts as they are an underutilised source of information for scholars of early European religious history. Scholars often overlook these prayer books (most likely because of the outdated editions of the texts), however, my research overall hopes to demonstrate the value of these manuscripts. In this article, I briefly outline the cultural context of these prayer books because, to understand the texts and uses of the manuscripts, one must understand their background and the environment that created them. Here, I focus on their Hiberno-Saxon heritage as, in my opinion; it is one of the most interesting features of the prayer books since it demonstrates the close links between Ireland and Anglo-Saxon England.

\section{Hiberno-Saxon}

While Irish influence in Northumbria is well described in current scholarship, similar cultural exchanges in Mercia are often overlooked; this is something that my research hopes to remedy.The Mercian prayer books exhibit signs of Irish influence and are called: the 
Book of Nunnaminster, the Royal Prayer Book, the Harleian Prayer Book and the Book of Cerne. These prayer books were produced in Mercia during the late eighth and early ninth centuries. The decoration of these manuscripts exhibit a fusion of Irish and Anglo-Saxon culture so knotted that their artwork would be better termed Hiberno-Mercian, meaning that they are influenced by both cultures. Manuscripts, such as these prayer books were produced in monasteries or nunneries. The early monastic culture of Anglo-Saxon England was strongly connected with Ireland, to the extent that the style of the artwork from this period (c. 600-900 AD) is often referred to as Hiberno-Saxon or Insular. The Book of Kells is one of the most famous artefacts associated with Irish history and it epitomises the combined Hiberno-Saxon culture. The Book of Kells is a seventh century illuminated (decorated) manuscript of the Gospels. While today the Book of Kells is linked with Irish culture, the place of its origin is uncertain as it could have been produced in Ireland or an area under Irish influence in northern England such as Iona. Though the manuscript is generally understood by many to be 'Irish', a more correct term would be Hiberno-Saxon or Insular, demonstrating this uncertainty and the closeness of these cultures.

How then did this combination of cultures occur? Irish monks such as Columba and Columbanus went on missions to preach the word of God across Europe and set up important monastic centres. Columba founded a monastery on an offshore island in northern England called Iona and Columbanus travelled as far as Bobbio in Italy, while another Irish missionary, Aidan, founded a monastery at Lindisfarne, another island off of the coast of England. Along with other ecclesiastical centres such as Wearmouth Jarrow, Lindisfarne and Iona became important centres of learning and culture. As Irish and Irish-trained monks taught the Anglo-Saxons, the cultures fused, to the extent that it sometimes difficult to differentiate between the two cultures (especially in terms of manuscript script and artwork) and the broader term 'Insular' culture is preferred.

\section{The Irish in Mercia}

Irish influence in Mercia is evident from the seventh century when Mercia converted to Christianity. The conversion is recounted in Bede's The Ecclesiastical History of the English People. This conversion was a consequence of a dynastic marriage. Marriages between important families strengthened political ties and helped to spread Christianity across Europe. The conversion of the southern kingdom Kent was a result of a marriage between the Kentish king, Æthelbertht, and a Merovingian princess, Bertha. The later Mercian conversion was also born of a political marriage. The Mercian Peada requested the hand of the daughter of Oswiu, a Christian king. Oswiu agreed to this alliance on the condition that Peada converted to Christianity. Peada agreed and was baptised by the Irish bishop Finan. Finan took four priests to Mercia with him: Adda, Betti, Cedd and Diuma. Diuma is described as natione Scottus ('an Irishman') and he became the first Mercian bishop. A line of Irish or Irish-educated bishops succeeded Diuma: Finn, Ceollach and Trumhere. 
This created a situation in Mercia where Irish and Irish-trained clergy led and taught the Mercians. This historically accounts for the Irish influence on the prayer books, as it was in this Hiberno-Saxon milieu that the four early Anglo-Saxon prayer books were produced.

\section{Hiberno-Saxon decoration of the prayer books}

\section{Zoomorphic lettering}

The decoration of the early prayer books possesses an Irish flavour as they contain decorated elements popularly associated with Celtic artwork. The patterns consist of interlocking swirls and spirals (interlace); the colours are rich, deep and bright. The opening letters of texts are often made up of animals, where the terminal (one end of the stroke of the letter) has animalistic features. These types of letters are described as zoomorphic letters. If the feature is human, then the letters are called anthropomorphic. A more accurate description of this artwork is Hiberno-Saxon as it is common in both Ireland and Anglo-Saxon England. Examples of this type of decoration include the Book of Kells and Lindisfarne Gospel Book. The Mercian prayer books contain examples of these decorative zoomorphic initials.

The Book of Nunnaminster and Royal Prayer Book exhibit fine examples of the zoomorphic initials. Pages in manuscripts are referred to as folios (fols); the ' $v$ ' or ' $r$ ' refers to the front ('verso') or the back ('recto') of the folio. On folio $17 \mathrm{v}$ of the Royal Prayer Book, there is a zoomorphic ' $\mathrm{N}$ '. The crossbar of the ' $\mathrm{N}$ ' is animal shaped. The Book of Nunnaminster has two major examples on folios $16 \mathrm{v}$ ('D'), $4 \mathrm{v}$ ('A'), 11v ('H') and other minor (much smaller) initials, such as on fol. 37v. The Royal Prayer Book ' $n$ ' is second letter of the word 'In'. The word takes up a quarter of the page. The down strokes of the 'I' and the ' $n$ ' are thick and black, and both letters are picked out by red dots. The down terminal of the ' $\mathrm{I}$ ' is decorated with a yellow fish head. The top of the terminal links with the first stokes of the ' $n$ ' and is coloured red, green and yellow. The first stroke of the ' $n$ ' finishes with a green dog head. The cross bar of the ' $n$ ' is zoomorphic; the animal is perhaps some form of reptile. The dark green creature is formed of a tail, no visible back leg but has at least one wing and its two arms link the around the ' $\mathrm{I}$ ' and the ' $\mathrm{n}$ '. The ' $\mathrm{H}$ ' on fol. $11 \mathrm{v}$ of the Book of Nunnaminster is the most complex decoration in the manuscript. The letter begins and ends with head of a creature; it is not discernible as a particular type of animal. The first creature head is green and yellow; the second is black with pointed ears, its tongue long and tangled. Unlike the Royal initial, the Nunnaminster ' $\mathrm{H}$ ' is not filled in but the shape of the letter consists of a fine black frame, and in between this frame, the letter consists of interlocking swirls. 


\section{Liber}

The opening page of the Royal Prayer Book contains a decorated initial: the word Liber (folio 1r). The letters are illuminated by gold and silver ink, denoting the importance of this word. The decorated initial Liber in Insular illuminated gospels generally marks a passge of the Gospel of Matthew (I.18). This passage of the gospel begins the recitation of Christ's human genealogy. Christ's human nature was as important as his divinity to Christians; the importance of his humanity is demonstrated visually through the elaborate decoration of this initial. The Liber initial of the Lindisfarne Gospel Book (fol. 29r) is probably the most spectacular example. The word Liber takes up a quarter of the page while the second letter ' $i$ ' descends to the bottom of the page. The initial is decorated with brightly coloured complex interlace and animal heads. While the 'er' is less ornate than the 'Lib', the 'e' still finishes with an animal head (possibly a duck).

\section{Book of Cerne Evangelist miniatures}

Unlike the other three Mercian prayer books, the Book of Cerne contains full page drawings (called miniatures). These miniatures are drawings of the four evangelists, Matthew (fol. 2v), Mark (fol. 12v), Luke (fol. 21v), John (fol. 31v), in their symbolical zoomorphic and human form. By zoomorphic form, I mean the animal symbol of the evangelist. Scribes would sometimes symbolically depict the evangelists. Each of these symbols highlights a particular aspect of that evangelist's gospel. Matthew is represented by a man because his Gospel underlines Christ's humanity. Mark's symbol is a lion signifying Christ's Resurrection. The bull symbolises Luke, this sometimes represents Christ's priesthood. John's symbol is an eagle, because his gospel is considered more allegorical than the other gospels. In the Book of Cerne, arches frame the evangelists; at the apex of each arch is a disc with a small portrait of the evangelist.

There are many similarities between these miniatures and Irish depictions of the evangelist: particularly images from manuscripts such as the Stowe Missal, the Book of Dimma, Cadmug Gospels, and the Book of Mullig but also other Hiberno-Mercian manuscripts such as the Stockholm Codex Aureus. The Stockholm Codex Aureus depiction of the evangelist is very similar to those in the Book of Cerne as the arches are present.

\section{Summation}

Mercia is often overlooked in the history of Anglo-Saxon and later medieval spirituality. My research seeks to redress this imbalance by demonstrating the importance of these manuscripts, and therefore Mercia, to the history of religious devotion. While the most famous surviving artefacts from the Anglo-Saxon golden age are Northumbrian, the earliest 
devotional prayer books are Mercian. The decoration and texts of these manuscripts are products of a Hiberno-Mercian milieu, demonstrating a strong Irish influence outside of Northumbria.

Many thanks to Dr Orla Murphy and Dr Mark Faulkner, School of English, University College Cork.

\section{Further Reading}

M. Brown, 'Echoes: the Book of Kells and Southern English Manuscript Production', in F. O'Mahony ed., The Book of Kells. Proceedings of a Conference at Trinity College Dublin, 1992 (Aldershot, 1994), pp. 333-43

- -., The Book of Cerne: Prayer, Patronage and Power in Ninth-Century England (London, 1996)

Zoomable and colour reproduction of images from the Book of Nunnaminster and Royal Prayer Book are available on the British Library website: http://www.bl.uk. 